\title{
Pengaruh Metode Two Stay Two Stray Terhadap Karakter Disiplin Siswa Pada Mata Pelajaran Akidah Akhlak Di MI Tarbiyatul Atfhal
}

\author{
Dwi Indah Lestari \\ Pendidikan Guru Madrasah Ibtidaiyah, Fakultas Agama Islam, Universitas Ibn \\ Khaldun Bogor \\ Email: dwiindahlestariii38@gmail.com \\ Maemunah Sa'diyah \\ Pendidikan Guru Madrasah Ibtidaiyah, Fakultas Agama Islam, Universitas Ibn \\ Khaldun Bogor \\ Email: maemunah@fai.uika-bogor.ac.id
}

\section{Kamalludin}

Pendidikan Guru Madrasah Ibtidaiyah, Fakultas Agama Islam, Universitas Ibn Khaldun Bogor

Email: Kamalludinawal66@gmail.com

\begin{abstract}
Abstrak
Tujuan dari penelitian ini yaitu untuk mengetahui ada atau tidaknya pengaruh penggunaan metode two stay two stray (TSTS) terhadap karakter disiplin siswa di MI Tarbiyatul Atfhal. Metode yang digunakan adalah penelitian eksperimen. Sampel penelitian ini meliputi 30 siswa kelas kontrol dan 30 siswa kelas eksperimen. Instrument penelitian berupa observasi, tes, dan dokumentasi. Hasil penelitian dihitung menggunakan SPSS 20 untuk mengetahui tingkat pengaruh metode pembelajaran. Hasil dari penelitian ini yaitu adanya pengaruh pada metode Two stay two stray terhadap karakter disiplin siswa pada mata pelajaran Akidah Akhlak pada kelas eksperimen dan kontrol di kelas V MI Tarbiyatul Athfal yaitu terdapat perbedaan rata-rata kedua kelas dengan nilai rata-rata kelas kontrol pre-test 47,2 dan post-test 71,2 . Sedangkan kelas eksperimen mendapatkan nilai rata-rata pre-test 49,07 dan post test 86,67. Maka dapat di simpulkan metode two stay two stray memiliki pengaruh terhadap karakter disiplin siswa di MI Tarbiyatul Atfhal.
\end{abstract}

Kata kunci: Karakter Disiplin, Metode Pembelajaran, Two stay two stray. 


\begin{abstract}
The purpose of this study is to determine whether or not there is an influence of the use of the two stay two stray (TSTS) method to the discipline character of students at MI Tarbiyatul Atfhal. The method used is experimental research. The sample of this study included 30 control class students and 30 experimental class students. Research instruments in the form of observation, tests, and documentation. The results of the study were calculated using SPSS 20 to determine the level of influence of the learning method. The results of this study are the influence of the Two Stay Two Stray method on the character of student discipline in the subjects of the Islamic Morals in the experimental and control classes in class V MI Tarbiyatul Athfal ie there are differences in the average of the two classes with the average value of the pre-control class test 47.2 and post-test 71.2. While the experimental class got an average score of 49.07 pre-test and 86.67 post-test. Then it can be concluded that the two stay two stray method has an influence on the character of student discipline at MI Tarbiyatul Atfhal.
\end{abstract}

Keywords: Disciplinary Character, Learning Method, Two Stay Two Stray.

\title{
Pendahuluan
}

Akidah-Akhlak di Madrasah Ibtidaiyah merupakan salah satu mata pelajaran PAI yang mempelajari tentang rukun iman yang dikaitkan dengan pengenalan dan penghayatan terhadap asmaul husna, serta penciptaan suasana keteladanan dan pembiasaan dalam mengamalkan akhlak terpuji dan adab Islami melalui pemberian contoh-contoh perilaku dan cara mengamalkannya dalam kehidupan sehari-hari. Secara substansial mata pelajaran Akidah-Akhlak memiliki kontribusi dalam memberikan motivasi kepada peserta didik untuk mempraktikkan akhlakul karimah dan adab Islami dalam kehidupan sehari-hari sebagai manifestasi dari keimanannya kepada Allah, malaikat-malaikat-Nya, kitab-kitab-Nya, rasul-rasul-Nya, hari akhir, serta Qada dan Qadar (Sholikhatun, 2011: 1).

Pendidikan akidah akhlak di Madrasah Ibtidaiyah memang bukan satusatunya faktor yang menentukan dalam pembentukan tingkah laku siswa. Apalagi dalam pelaksanaan pendidikan akidah akhlak tersebut masih terdapat kelemahan-kelemahan yang mendorong dilakukannya penyempurnaan terusmenerus.

Kelemahan tersebut terdapat pada materi pendidikan akidah akhlak yang lebih terfokus pada pengayaan pengetahuan (kognitif) dan minim dalam pembentukan sikap (afektif) serta pembiasaan (psikomotorik). Lalu lemahnya sumber daya guru dalam pengembangan pendekatan dan metode 
yang lebih variatif, minimnya berbagai sarana pelatihan dan pembangunan, serta rendahnya peran serta orang tua siswa (Pratiwi, 2018:3).

Pendidikan karakter bagi anak usia dini adalah untuk menanamkan nilai-nilai kebaikan supaya dapat menjadi kebiasaan ketika kelak dewasa atau pada jenjang pendidikan selanjutnya. Adapun, nilai-nilai karakter yang harus diajarkan kepada peserta didik sejak lahir adalah sifat dapat dipercaya, disiplin. jujur, rasa hormat dan perhatian, peduli, tanggung jawab, ketulusan, berani, tekun, visioner, adil dan punya integritas

Pendidikan karakter disiplin ini sudah seharusnya dikenalkan pada anak dari sejak dini. Disiplin ini adalah membiasakan diri mematuhi peraturan atau kesepakatan yang ada dan melakukan suatu perbuatan yang baik. Pengembangan karakter dapat dilakukan melalui pendidikan, baik pendidikan formal disekolah, pendidikan nonformal dimasyarakat maupun pendidikan informal didalam keluarga. Pada lembaga formal atau sekolah pendidikan karakter terbentuk melalui kegiatan modeling oleh guru-guru warga sekolah (Wahyuni, 2014: 3).

Berdasarkan permasalahan diatas, maka peneliti melakukan sebuah tindakan dengan menerapkan metode two stay two stray. Dalam pembelajaran ini siswa akan lebih aktif berbagi pengetahuan dan dalam memahami materi pelajaran. Menurut Miftahul Huda (2014: 207) Metode two stay two stray merupakan sistem pembelajaran kelompok dengan tujuan agar siswa dapat saling bekerja sama, bertanggungjawab, saling membantu memecahkan masalah, dan saling mendorong satu sama lain untuk berprestasi (Huda, 2014: 207).

1. Rumusan masalah.

Berdasarkan uraian di atas, peneliti merumuskan masalah sebagai berikut:

1) Adakah pengaruh Metode Two Stay Two Stray terhadap karakter disiplin siswa pada mata pelajaran Akidah Akhlak pada kelas eksperimen dan control di kelas V MI. Tarbiyatul Athfal?

2. Tujuan penelitian

Berdasarkan rumusan masalah di atas, penulisan artikel ini bertujuan untuk:

1) Untuk mengetahui pengaruh Metode Two Stay Two Stray terhadap karakter disiplin siswa pada mata pelajaran Akidah Akhlak pada kelas eksperimen dan kontrol di kelas V MI. Tarbiyatul Athfal

\section{Metode Penelitian}

Penelitian ini menggunakan penelitian eksperimen, dengan jenis data kuantitatif, jenis penelitian eksperimen semu (Quasi Experimental). Dalam penelitian ini peneliti menggunakan dua kelompok yaitu kelas eksperimen dan kelas kontrol. Kelas eksperimen adalah kelompok yang diberikan perlakuan menggunakan metode two-stay-two-stray, sedangkan kelas kontrol adalah kelas yang tidak diberikan 
perlakuan. Dalam desain penelitian ini baik kelompok eksperimen maupun kontrol sama-sama diberi tes (pre-test) kemudian mendapakan hasilnya. Setelah itu, kelompok eksperimen mendapatkan perlakuan menggunakan metode two stay two stray sedangkan kelompok kontrol tidak. Keduanya mendapatkan tes kembali (posttest) setelah melakukan proses pembelajaran untuk mengetahui hasil perlakuan yang telah dilakukan.

Metode two stay two stray diawali dengan pembagian kelompok, setelah kelompok terbentuk guru memberikan tugas permasalahan yang harus didiskusikan jawabannya. Langkah-langkah metode two stay two stray adalah: Langkah Pertama, peserta didik bekerjasama dalam kelompok berempat seperti biasa. Langkah Kedua, dua orang dari masing-masing kelompok bertamu ke kelompok lain. Langkah Ketiga, dua orang yang tinggal dalam kelompok bertugas membagikan hasil dan informasi mereka ke tamu mereka. Langkah Keempat, tamu mohon diri dan kembali ke kelompok mereka masing-masing dan melaporkan temuan mereka dari kelompok lain. Langkah Kelima, kelompok mencocokkan dan membahas hasil kerja mereka.

Penelitian ini dilakukan di MI Tarbiyatul Athfal Bogor yang dilakukan di dua kelas yaitu kelas $\mathrm{V}$ dengan murid yang belajar menggunakan metode two stay two stray. Waktu yang ditempuh dalam penelitian ini sekitar 2-3 bulan yaitu pada bulan September sampai awal bulan November 2019. Sampel dalam penelitian ini berjumlah 60 orang, terdiri dari dua kelas, yaitu kelas 5A sebanyak 30 siswa, dan 5B sebanyak 30 siswa. Teknik pengumpulan data yang digunakan yaitu observasi, tes dan dokumentasi.

\section{Hasil Dan Pembahasan}

Dari data-data penelitian yang telah dianalisis, diperoleh data hasil belajar siswa pada kelas eksperimen dan kelas kontrol. Dapat disimpulkan bahwa terdapat perbedaan rata-rata kedua kelas tersebut dengan nilai rata-rata kelas kontrol pre-test 47,2 dan post-test 71,2. Sedangkan kelas eksperimen mendapatkan nilai rata-rata pretest 49,07 dan post test 86,67. Dapat disimpulkan bahwa terdapat perbedaan yang signifikan antara kedua kelas tersebut dimana kelas eksperimen jauh lebih unggul dibandingkan dengan kelas kontrol. Hal tersebut karena kelas eksperimen menggunakan metode two stay two stray sedangkan kelas kontrol menggunakan pendekatan konvensional (ceramah).

Pada kelas kontrol yang diberikan pembelajaran dengan menggunakan pendekatan konvensional (ceramah), pada saat pembelajaran dimulai, siswa diberikan tes awal terlebih dahulu sama seperti kelas eksperimen untuk mengetahui pemahaman siswa terhadap pelajaran akidah akhlak. Sedangkan tes akhir diberikan kepada siswa setelah diberikan pemahaman dan materi tentang satuan berat. Pendekatan konvensional hanya memberikan penjelasan materi saja yang bersifat monoton dan siswa hanya memperhatikan saja. Sehingga tujuan pembelajaran tidak tercapai sesuai dengan yang diharapkan, Sedangkan di kelas eksperimen dengan 
menggunakan metode two stay two stray, pada saat proses pembelajaran dimulai, sama seperti kelas kontrol siswa diberika tes awal terlebih dahulu setelah itu diberikan perlakuan dengan menggunakan metode two stay two stray.

Hasil pengamatan penilaian karakter disiplin siswa kelas 5 di MI Tarbiyatul Athfal yaitu kelas kontrol dan kelas eksperimen dalam kegiatan pembelajaran akidah akhlak di kelas kontrol dengan menggunakan pendekatan konvensional hanya sedikit mengalami peningkatan dan di kelas eksperimen mengalami peningkatan. Dapat disimpulkan bahwa terdapat perbedaan nilai rata-rata pada kedua kelas tersebut dimana kelas kontrol mendapatkan nilai rata-rata pre-test 14,47 dan post-test 22,13 dan kelas eksperimen nilai rata-rata pre-test 15,3 dan post-test 29,83.

Untuk mendapatkan perbedaan pada hasil belajar dan karakter antara kelas kontrol dan kelas eksperimen yaitu dengan menggunakan metode two stay two stray pada kelas eksperimen. Dimana metode two stay two stray merupakan pembelajaran yang diawali dengan pembagian kelompok. Setelah kelompok terbentuk guru memberikan tugas berupa permasalahan-permasalahan yang harus siswa diskusikan jawabannya (Febriyanti dkk: 2013)

Sedangkan kelas kontrol hanya menggunakan pembelajaran konvensional (ceramah). Menurut Djamarah (2010: 97) metode ceramah adalah metode yang boleh dikatakan tradisional karena sejak dulu metode ini telah digunakan sebagai alat komunikasi lisan antara guru dengan anak didik dalam proses belajar dan mengajar. Pembelajaran model konvensional ditandai dengan ceramah yang diiringi dengan penjelasan, serta pembagian tugas dan latihan.

Berdasarkan hasil perhitungan pre-test dan post-test menggunakan paired sample $t$ test pada kelas eksperimen dan kelas kontrol, maka untuk membandingkan data post-test dari kedua kelas tersebut menggunakan independent sample $t$ test sebagi berikut:

Tabel 1.1 Independent Sample Test

\begin{tabular}{|c|c|c|c|c|c|c|c|}
\hline & $\begin{array}{c}\text { Levene's } \\
\text { Test for } \\
\text { Equality } \\
\text { of } \\
\text { Variance } \\
\text { s }\end{array}$ & \multicolumn{8}{|c|}{ t-test for Equality of Means } \\
\hline F & Sig & T & Df & $\begin{array}{c}\text { Sig. } \\
2- \\
\text { taile } \\
\text { d) }\end{array}$ & $\begin{array}{c}\text { Mean } \\
\text { ifferen } \\
\text { ce }\end{array}$ & $\begin{array}{c}\text { Std. } \\
\text { Error } \\
\text { Differen } \\
\text { ce }\end{array}$ & $\begin{array}{c}\text { Confidence } \\
\text { Interval of the } \\
\text { Difference }\end{array}$ \\
\cline { 3 - 7 } & & & & & & Lower & Upper \\
\hline
\end{tabular}




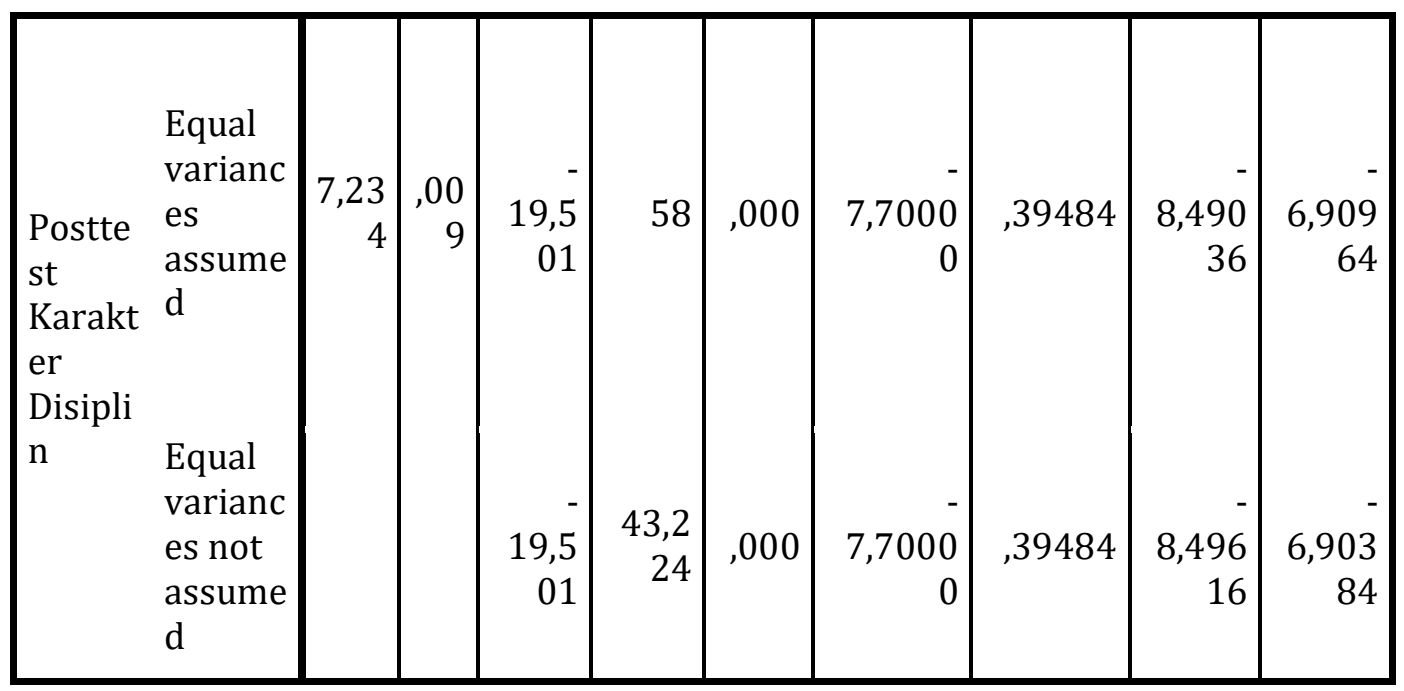

Berdasarkan pehitungan independent sample ttest pada kelas eksperimen dan kelas kontrol diperoleh hasil t hitung adalah -19,501 dengan jumlah siswa 30 orang. Pengambilan keputusan melihat dari hasil sig. (2-tailed) adalah 0,000 hal ini menunjukan bahwa angka tersebut lebih kecil dari 0,05. Pengambilan keputusan ini didasari oleh sig. (2-tailed) lebih kecil dari 0,05 atau Ha diterima, maka terdapat perbedaan yang signifikan antara nilai rata-rata post-test pada kelas eksperimen dan kelas kontrol. Dapat disimpulkan bahwa terdapat peningkatan karakter disiplin.

Dengan demikian dapat disimpulkan bahwa terdapat perbedaan antara data kedua kelas tersebut dimana kelas eksperimen lebih signifikan serta lebih unggul dibandingkan dengan kelas kontrol. Hal tersebut karena kelas eksperimen mendapatkan perlakuan dengan menggunakan metode two stay two stray dibandingkan dengan kelas kontrol yang hanya menggunakan metode ceramah.

\section{Kesimpulan}

Ada pengaruh pada metode Two Stay Two Stray terhadap karakter disiplin siswa pada mata pelajaran Akidah Akhlak pada kelas eksperimen dan control di kelas V MI. Tarbiyatul Athfal yaitu terdapat perbedaan rata-rata kedua kelas dengan nilai rata-rata kelas kontrol pre-test 47,2 dan post-test 71,2 . Sedangkan kelas eksperimen mendapatkan nilai rata-rata pre-test 49,07 dan post test 86,67 . Terdapat perbedaan yang signifikan antara kedua kelas tersebut dimana kelas eksperimen jauh lebih unggul dibandingkan dengan kelas kontrol. Hal tersebut karena kelas eksperimen menggunakan metode two stay two stray sedangkan kelas kontrol menggunakan pendekatan konvensional (ceramah).

Pada kelas kontrol yang diberikan pembelajaran dengan menggunakan pendekatan konvensional (ceramah), pada saat pembelajaran dimulai, siswa diberikan tes awal terlebih dahulu sama seperti kelas eksperimen untuk mengetahui pemahaman siswa terhadap pelajaran akidah akhlak. Sedangkan tes akhir diberikan kepada siswa setelah diberikan pemahaman dan materi tentang satuan berat. Pendekatan konvensional hanya memberikan penjelasan materi saja yang bersifat 
monoton dan siswa hanya memperhatikan saja. Sehingga tujuan pembelajaran tidak tercapai sesuai dengan yang diharapkan.

Dengan demikian dapat disimpulkan bahwa terdapat perbedaan antara data kedua kelas tersebut dimana kelas eksperimen lebih signifikan serta lebih unggul dibandingkan dengan kelas kontrol. Hal tersebut karena kelas eksperimen mendapatkan perlakuan dengan menggunakan metode two stay two stray dibandingkan dengan kelas kontrol yang hanya menggunakan metode ceramah.

\section{Referensi}

Djamarah, S.B. 2010. Strategi Belajar Mengajar. Rineka Cipta: Jakarta.

Febriyanti, E.A.W., Jampei, I, N., Syahruddin. 2014. Pengaruh Metode Pembelajaran Two Stay Two Stray Berbantuan Media Konkret Terhadap Hasil Belajar Siswa Kelas 5. Jurnal Mimbar Pgsd Universitas Pendidikan Ganesha. 2(1)

Huda, M. (2014). Model-model Pengajaran dan Pembelajaran. Yogyakarta: Pustaka Pelajar.

Pratiwi, R. 2018. Pengaruh Pembelajaran Akidah Akhlak Terhadap Prilaku Peserta Didik Di MIN 2 Makasar. Skripsi. Universitas Islam Negeri Alauddin Makasar.

Sholikhatun R. 2011. Problematika Pembelajaran Akidah Akhlak Di MI Surodadi 1 Sawangan Magelang. Skripsi. Institut Agama Islam Negeri Walisongo Semarang.

Wahyuni. (2014). Pendidikan Karakter Disiplin Pada Anak Usia 5-6 Tahun. Skripsi. Universitas Tanjung Pura Pontianak. 